\title{
Keyword Index to Volume 40, 2015
}

(Page numbers with J indicate keywords in the contents published in Japanese Journal of Pesticide Science.)

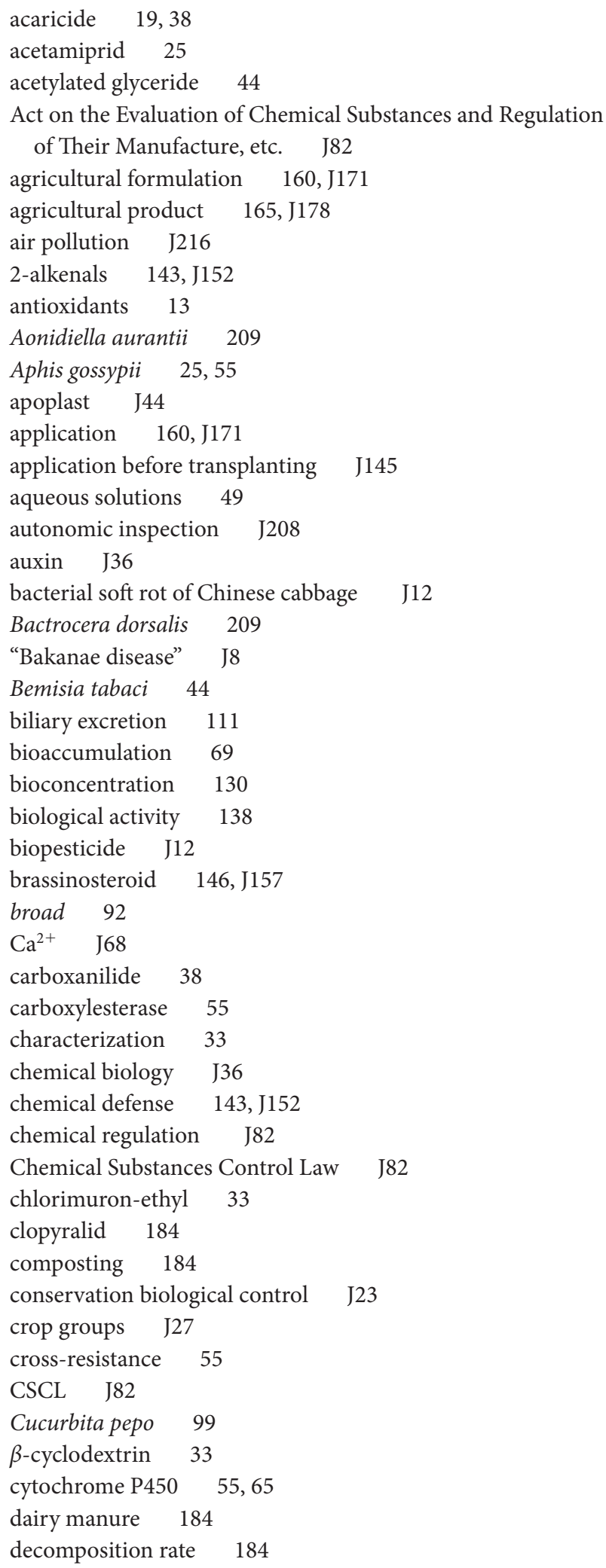

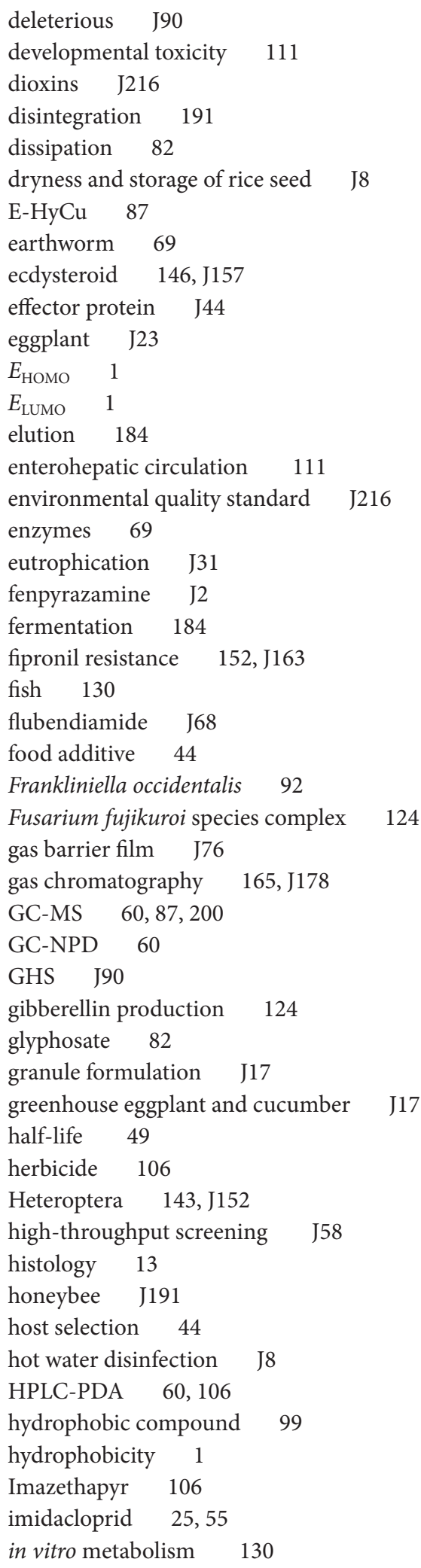




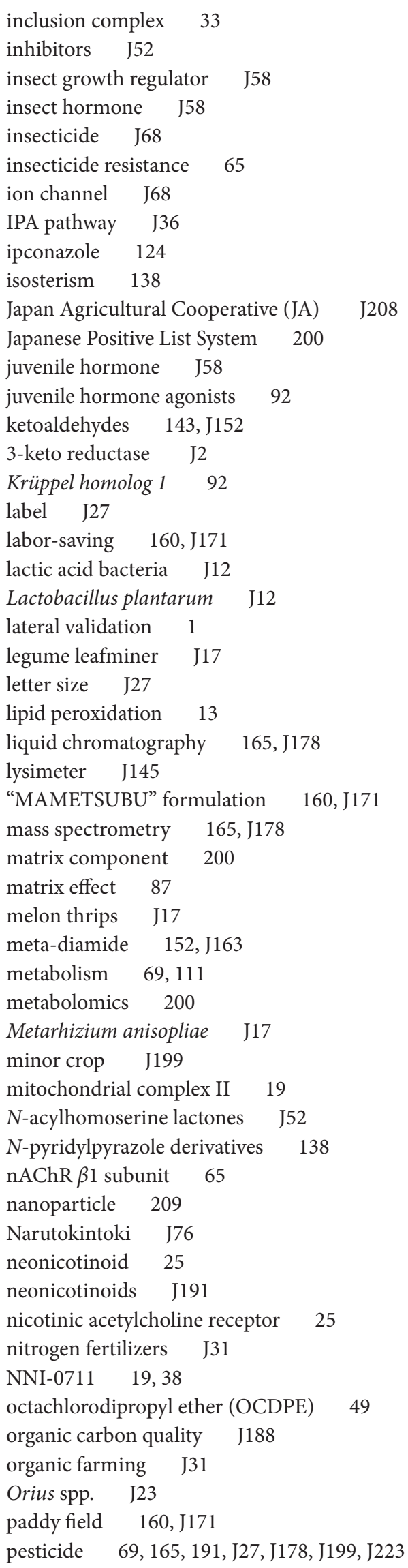




$\begin{array}{lll}\text { terminal residues } & 106 \\ \text { tetramethrin } 130 & \\ \text { Tetranychus urticae } & 19 \\ \text { thrips J23 } & & \\ \text { Thysanoptera } & 65 & \\ \text { TIR1 receptor } & \text { J36 } & \\ \text { toxicity } \quad \text { 13, } 69 & \\ \text { trans-laminar ability } & \text { J2 } \\ \text { translocation } & 99 & \\ \text { transportation } & 215 & \\ \text { 1,2,3-triazole } & 138 & \end{array}$

\author{
uptake pathway 99 \\ water dispersible granule (WDG) 191 \\ water pollution J216 \\ water pollution control act J223 \\ water-extraction of soil 175 \\ X-phenols 1 \\ xylem 99 \\ xylem sap 215 \\ yuza (Citrus junos) and yuza tea 60 \\ Z-Sep/C18 87 \\ Z-Sep $+\quad 87$
}

